Kolarova, E., Kolarova, V., Homola, D. (2019). The Impact of Errors in the Area of Taxable Expenses and Revenues on Economic Indicators. Journal of Competitiveness, 11(1), 41-51. https://doi.org/10.7441/ joc.2019.01.03

\title{
THE IMPACT OF ERRORS IN THE AREA OF TAXABLE EXPENSES AND REVENUES ON ECONOMIC INDICATORS
}

\section{- Eva Kolarova, Vendula Kolarova, David Homola}

\begin{abstract}
Basic financial indicators are based on accounting information. These indicators help to manage and plan every business and are quite important in the performance assessment of accounting units. The road to success for every business is to increase its competitiveness, which is not possible without access to the proper information. This article briefly describes the effect of accounting errors, mainly in the area of taxable expenses and revenues, on economic indicators. The aim of the article is to present research results focused on reasons for the occurrence of inaccurate accounting information and its impact on economic indicators. The first part of the paper analyses the error rate in individual areas of accounting. The difficulty of valuation, adjustments, depreciation, tax impacts and the accruals were proven to be the riskiest areas and the subsequent research focused on them. The second part of the research focused on the use of economic indicators in companies and the influence of errors on firms' ability to provide information. The data were processed using descriptive statistics and statistical analysis methods. In the following discussion, special attention was devoted to the distortion of economic indicators due to bad accounting information, the occurrence of which was statistically confirmed.
\end{abstract}

Keywords: accounting, inaccurate information, tax base, economic indicators JEL Classification: $M 21, M 41$

Received: June, 2018

1st Revision: January, 2019

Accepted: February, 2019

\section{INTRODUCTION}

High-quality accounting information is the basis for the financial management of companies with respect to their competitiveness. Data from the financial statements can provide information on the financial position, the performance of the company and the ability to capitalize on funds. Without understanding the basic principles of accounting, it is not possible to discuss the quality of financial management, on which the success of any company is dependent. Ensuring good accounting information, which encompasses many factors, is becoming increasingly complex. Continuous legislative changes put pressure on company management and accountants, whether from the owners, creditors, control bodies, or in terms of the knowledge and skills of the accountants themselves. Quality data is important for financial analysis. In the narrower 
sense, financial analysis examines accounting data to obtain an overview of the company's assets and financial situation, which can lead management to make decisions about further development of the company.

This article focuses on the quality of accounting data and the resulting impact on economic indicators of financial analysis. The article presents research results from years 2016 and 2017.

\section{THEORETICAL BACKGROUND}

The issue of accounting and taxes in the literature is so extensive and complex that attempting to avoid accounting errors using this plethora of information is an extremely difficult task. The accounting data are examined from a variety of perspectives and in many different contexts and levels: as part of company management, performance management, finance and cash management, risk management and marketing and business policies (Kubicková \& Soucek, 2013).

With the increasing importance of accounting information as the primary source for the decision-making processes of their internal and external users, emphasis is also placed on quality. Bai (2012) confirms that the quality of data contained in accounting information systems has a significant impact on both internal and external compliance. Zoto (2014) states that the data quality is crucial in today's business conditions, as it is firmly linked to a set of data suitable for use by people who use, interpret and use relevant data in their work. Bašta (2006) also adds that a more faithful, honest and truthful image of a company can be achieved by objectively processing obtained data into the financial statements rather than by analysing financial statements themselves. A number of researches directly or indirectly concerning the quality of accounting information has been undertaken in the Czech Republic as well as around the world. For example, according to Porter \& Norton (2015), as well as Puican et al. (2011), this information should be comprehensible, relevant, faithful to reality, comparable and consistent. Nusa (2015) found in her research that the quality of accounting information can be significantly influenced by the human factor or corporate culture of the company. Chaney, Faccio, \& Parsley (2011) have proved that mistakes in accounting can occur both inadvertently and deliberately, with both types of errors reducing the quality of accounting information. Many scientists have researched and published on the topic of accounting information quality and creative accounting in a wider context, e.g. Cernusca et al. (2016), Jones (2011), Turkmen (2016), Deacon et al. (2016), Krištofik et al. (2016).

Explaining and understanding the function, fundamentals, and accounting rules will enable managers to use the accounting information for business management and decision making better. Management of all economic processes, including asset management in corporate decisionmaking, must be based on managerial and financial accounting (Otrusinová \& Šteker, 2013). Financial statements represent the main source of primary information for financial analysis (Knápková et al., 2012). Financial analysis is an investigation that must be carried out in a logical order. It comprises parts that are interlinked and should not therefore be carried out in isolation. Financial analysis is constantly striving to introduce a logical succession of criteria, as well as searching for any distracting factor that can be a prelude to future problems. In Fridson (2011), the primary goal in financial reporting is the dissemination of financial statements that accu- 
rately measure the profitability and financial condition of a company.

An error is a certain deviation from the standards or required situation that may result from a violation of the rules. Errors in accounting occur in companies mainly due to two reasons. The first cause is human factor failure, the second the failure of the information technology. Human factor failure can be further broken down into intentional errors, lack of information in the company, inattention, and insufficient knowledge of the company (Dušek, 2011). Additionally, we can distinguish between significant and insignificant errors. Depending on the size, implications and consequences of these errors, they can be divided into significant and insignificant. Significant mistakes include a violation of basic accounting principles, misplaced or calculated amounts, calculating using incorrect rates or using incorrect accounts for accounting transactions. One example of an insignificant error is the use of an incorrect archiving process (Dušek, 2011). A tax error can arise when the profit or loss is adjusted to calculate the tax base by a misstatement of tax liabilities and deductions.

\section{RESEARCH OBJECTIVE, METHODOLOGY AND DATA}

Our study was conducted in 2017 and 2018 and was based on a questionnaire survey. The questionnaire content included inquiries about the reasons why false financial information is generated. The questionnaires were directed not only to the creators of accounting information, primarily to accountants, but also to its users and other stakeholders in the process. They dealt with both the quality of accounting information and the use of economic indicators for corporate governance. The aim was to determine whether the quality of accounting information affects the reporting capacity of economic indicators, as well as to present the results of the research from the field of the reasons for the occurrence of erroneous accounting information.

The first section of the research analyzed the error rate in various areas of accounting. The riskiest areas were selected and a further survey focusing on the difficulty of valuation, adjustments, depreciation, tax impacts and the accruals was conducted. The second part focused on the use of economic indicators in companies and the influence of errors on their ability to provide information. From the research on the use of economic indicators, those indicators most often used by the companies were selected. From economic indicators, EVA Economic Value Added, OEE Overall Equipment Effectiveness, EBITDA Earnings Before Interest, Taxes, Depreciation and Amortization, BSC Balanced Scorecard, Z-score, Liquidity indicators, Profitability indicators, Debt indicators and Activity indicators were tested.

A total of 201 firms ranging from micro to large companies participated in the first survey. The structure of respondents is shown in Figure 1.

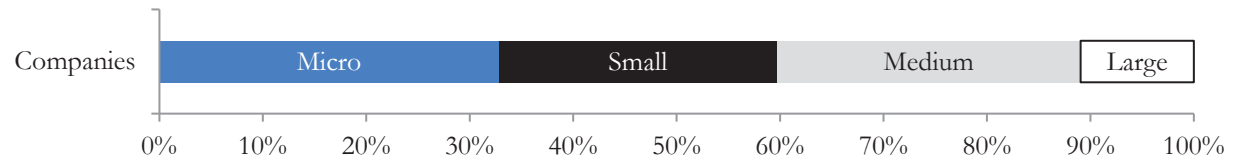

Fig. 1 - The structure of surveyed companies in the first survey. Source: authors' own 
A total of 282 companies from micro to large companies participated in the second survey. The structure of respondents is shown in Figure 2.

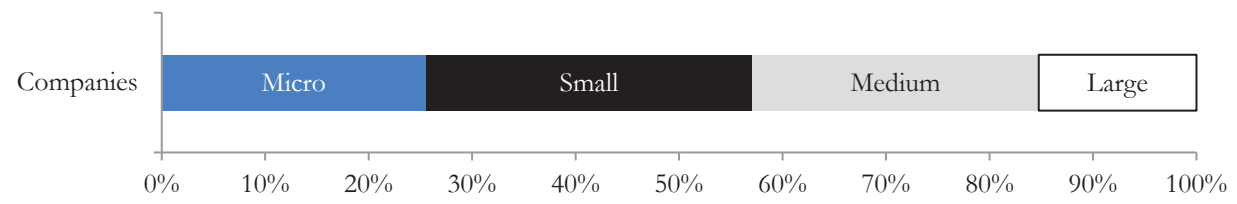

Fig. 2 - The structure of surveyed companies in the second survey. Source: authors' own

\section{Research methods}

The research method was a questionnaire survey. Most of the questionnaires consisted of statements pertaining to perceived risk of error and the use of economic indicators or the tax base impacts. The responses were analysed, and the results statistically processed. Several statistical procedures were used. To compare several sets of data, basic characteristics such as arithmetic mean, spread and standard deviation were used. In addition, the most commonly used hypothesis testing of the difference between two populations means was used to compare two sets of data. On this basis, judgments were made about these sets of data.

\section{Research questions:}

Can accounting errors affect the economic indicator?

Based on the research questions, the following hypotheses were formulated:

Formulations of hypothesis were as follows, specifically for the area of taxable expenses:

$\mathrm{H}_{0}$ - Insignificant errors in the area of taxable expenses influence economic indicators in the same way as do minor errors.

$\mathrm{H}_{1}$ - Insignificant errors in the area of taxable expenses do not influence economic indicators in the same way as do minor errors.

Formulations of hypothesis were as follows, specifically for the area of revenues:

$\mathrm{H}_{0}$ - Insignificant errors in the revenue area influence economic indicators in the same way as do minor errors.

$\mathrm{H}_{1}$ - Insignificant errors in the revenue area do not influence economic indicators in the same way as do minor errors.

\section{RESULTS AND DISCUSSION}

Two surveys were conducted. In 2017, research was carried out that dealt with errors throughout the entire range of accounting areas, e.g. errors of fixed assets, financial assets, inventories, accruals, expenses, receivables, equity and revenues in the areas of valuation, adjustments, tax impacts and accruals. 201 firms from the Czech Republic were asked whether they considered a 
given accounting area to be problematic in terms of reporting errors, and they were then asked to state the cause of issue. The results indicate the percentage of companies that consider the area to be problematic.

Tab. 1 - The percentage of companies which consider accounting items as problematic. Source: authors' own

\begin{tabular}{|l|l|l|l|l|l|}
\hline & Valuation & Adjustments & Depreciation & Tax impacts & Accruals \\
\hline Fixed assets & $44 \%$ & $34 \%$ & $17 \%$ & $58 \%$ & $0 \%$ \\
\hline Financial assets & $44 \%$ & $0 \%$ & $0 \%$ & $48 \%$ & $0 \%$ \\
\hline Liabilities & $14 \%$ & $0 \%$ & $0 \%$ & $54 \%$ & $0 \%$ \\
\hline Inventories & $54 \%$ & $48 \%$ & $0 \%$ & $21 \%$ & $0 \%$ \\
\hline Accruals & $24 \%$ & $0 \%$ & $0 \%$ & $75 \%$ & $3 \%$ \\
\hline Expenses & $24 \%$ & $0 \%$ & $0 \%$ & $85 \%$ & $3 \%$ \\
\hline Receivables & $10 \%$ & $58 \%$ & $0 \%$ & $51 \%$ & $0 \%$ \\
\hline Equity & $31 \%$ & $0 \%$ & $0 \%$ & $20 \%$ & $0 \%$ \\
\hline Revenue & $7 \%$ & $0 \%$ & $0 \%$ & $68 \%$ & $0 \%$ \\
\hline
\end{tabular}

The table shows that from the point of error occurrence, companies consider the tax area to be the most problematic. Based on these results, the next table shows the percentage of errors in the individual areas that affect the tax base.

Tab. 2 - Tax impacts of errors. Source: authors' own

\begin{tabular}{|l|l|}
\hline Area of error & Tax impacts \\
\hline Fixed assets & $20.56 \%$ \\
\hline Financial assets & $17.02 \%$ \\
\hline Liabilities & $19.15 \%$ \\
\hline Inventories & $7.45 \%$ \\
\hline Accruals & $26.59 \%$ \\
\hline Expenses & $30.14 \%$ \\
\hline Receivables & $18.09 \%$ \\
\hline Equity & $7.09 \%$ \\
\hline Revenue & $24.11 \%$ \\
\hline
\end{tabular}

The table shows that errors that have a tax impact are most likely to appear in the expenses, accruals and revenues area.

In our research we also addressed the following question:

Do your accounting errors affect your accounting statements? 


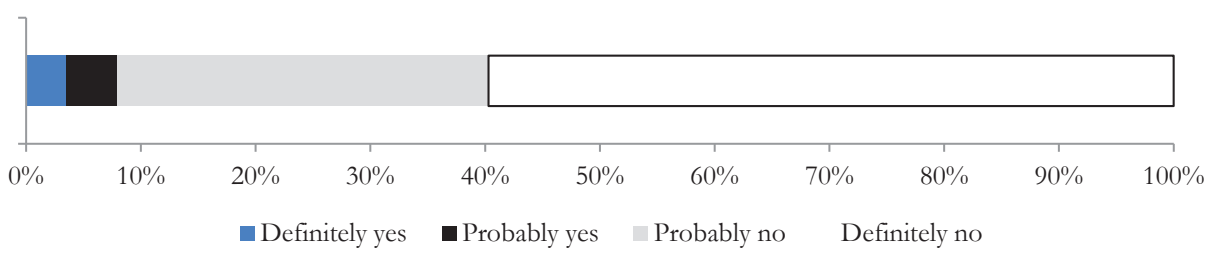

Fig. 3 - Answers to the question "Do your accounting errors affect your accounting statements?". Source: authors' own

The chart shows that $5.97 \%$ of respondents are convinced that errors will affect financial statements.

In 2018, further research was carried out which examined the quality of accounting information and included questions about economic indicators. Altogether 282 companies replied to the questionnaire. One of the key questions in the questionnaire was whether the surveyed companies were calculating financial indicators for the purposes of making strategic decisions. The results were as follows: $58.2 \%$ of companies calculate economic indicators for strategic decisions, and $62 \%$ of companies process economic indicators for the assessment of their financial performance.

In addition, the research dealt with the most frequently utilized economic indicators used for monitoring of company performance and management, which are dealt with in Table 3.

Tab. 3 - Utilized economic indicators. Source: authors' own

\begin{tabular}{|l|l|l|l|l|}
\hline & Yes & Sometimes & We do not use & We do not know \\
\hline EVA & $17.39 \%$ & $20.29 \%$ & $39.13 \%$ & $23.19 \%$ \\
\hline OEE & $26.09 \%$ & $15.94 \%$ & $36.23 \%$ & $21.74 \%$ \\
\hline EBITDA & $47.83 \%$ & $17.39 \%$ & $18.84 \%$ & $15.94 \%$ \\
\hline Z-score & $4.35 \%$ & $13.05 \%$ & $50.72 \%$ & $31.88 \%$ \\
\hline $\begin{array}{l}\text { Liquidity indi- } \\
\text { cators }\end{array}$ & $30.43 \%$ & $30.43 \%$ & $26.09 \%$ & $13.04 \%$ \\
\hline $\begin{array}{l}\text { Profitability } \\
\text { indicators }\end{array}$ & $31.88 \%$ & $33.33 \%$ & $24.64 \%$ & $10.15 \%$ \\
\hline Debt indicators & $31.88 \%$ & $27.54 \%$ & $30.43 \%$ & $10.15 \%$ \\
\hline $\begin{array}{l}\text { Activity indica- } \\
\text { tors }\end{array}$ & $34.78 \%$ & $21.74 \%$ & $31.89 \%$ & $11.59 \%$ \\
\hline
\end{tabular}

The most commonly used indicators are profitability-oriented. From an accounting point of view, these indicators mostly affect taxable expenses and revenues.

The following research was focused on the influence of particular selected accounting areas on economic indicators. 
Tab. 4 - Economic indicator dependability on accounting items. Source: authors' own

\begin{tabular}{|l|l|l|l|l|l|l|l|l|}
\hline & EVA & OEE & EBITDA & Z-score & $\begin{array}{l}\text { Liquid- } \\
\text { ity } \\
\text { indica- } \\
\text { tors }\end{array}$ & $\begin{array}{l}\text { Profit- } \\
\text { ability } \\
\text { indica- } \\
\text { tors }\end{array}$ & $\begin{array}{l}\text { Debt } \\
\text { indic. }\end{array}$ & $\begin{array}{l}\text { Activity } \\
\text { indica- } \\
\text { tors }\end{array}$ \\
\hline Fixed assets & & & & $\checkmark$ & & $\checkmark$ & & $\checkmark$ \\
\hline Financial assets & & & & $\checkmark$ & & & & $\checkmark$ \\
\hline Liabilities & & & & & $\checkmark$ & & $\checkmark$ & \\
\hline Inventories & & $\checkmark$ & & $\checkmark$ & $\checkmark$ & & & $\checkmark$ \\
\hline Accruals & & & & & & & & \\
\hline Expenses & $\checkmark$ & & $\checkmark$ & $\checkmark$ & & $\checkmark$ & & $\checkmark$ \\
\hline Receivables & & & & $\checkmark$ & & & & $\checkmark$ \\
\hline Equity & $\checkmark$ & & & $\checkmark$ & & & $\checkmark$ & \\
\hline Revenue & $\checkmark$ & & $\checkmark$ & $\checkmark$ & & $\checkmark$ & & \\
\hline
\end{tabular}

The table shows that economic indicators most greatly influence accounting taxable expenses, revenues and inventories. Therefore, indicators for the most affected expenditures and revenues were selected for the following surveys.

To be able to compare the influence of economic indicators, we identified errors in taxable expenses and revenues that occur only after financial statements, and divided these into insignificant, minor and significant categories. The results showed that errors in financial statements were identified only subsequently in $13.1 \%$ of cases. Insignificant errors in the interval $(0.01 ; 0.09)$ represented $78.4 \%$ of errors in the survey; minor errors in the interval $(0.1 \% ; 0.9$ $\%$ comprised $21.6 \%$ of errors, and significant errors of more than $1 \%$ were not present in the researched results.

Two intervals for insignificant and minor errors that affect economic indicators were used, and the percentage of influence was calculated. The results for insignificant errors can be seen in the following table.

Tab. 5 - The impact of insignificant errors on economic indicators. Source: authors' own

\begin{tabular}{|l|l|l|}
\hline $\begin{array}{l}\text { Impact of errors on } \\
\text { economic indicators }\end{array}$ & $\begin{array}{l}\text { Insignificant errors in the area } \\
\text { of expenses } \\
0,01 \%-0,09 \% \text { of error rate }\end{array}$ & $\begin{array}{l}\text { Insignificant errors in the area } \\
\text { of revenues } \\
0,01 \%-0,09 \% \text { of error rate }\end{array}$ \\
\hline EVA & $0.00296 \%$ & $0.00236 \%$ \\
\hline EBITDA & $0.00591 \%$ & $0.00473 \%$ \\
\hline Z-score & $0.00296 \%$ & $0.00236 \%$ \\
\hline ROS & $0.00390 \%$ & $0.00633 \%$ \\
\hline ROC & $0.00792 \%$ & $0.00312 \%$ \\
\hline & & \\
\hline
\end{tabular}




\begin{tabular}{|l|l|l|}
\hline Arithmetic mean & $0.00473 \%$ & $0.00378 \%$ \\
\hline Spread & $0.00000370 \%$ & $0.00000237 \%$ \\
\hline Standard deviation & $0.00192 \%$ & $0.00154 \%$ \\
\hline
\end{tabular}

For more clear understanding impacts of errors in areas of expenses and revenues were presented in form of boxplots divided according to relative size of errors from statistical software SPSS in figure 4 and 5 below.

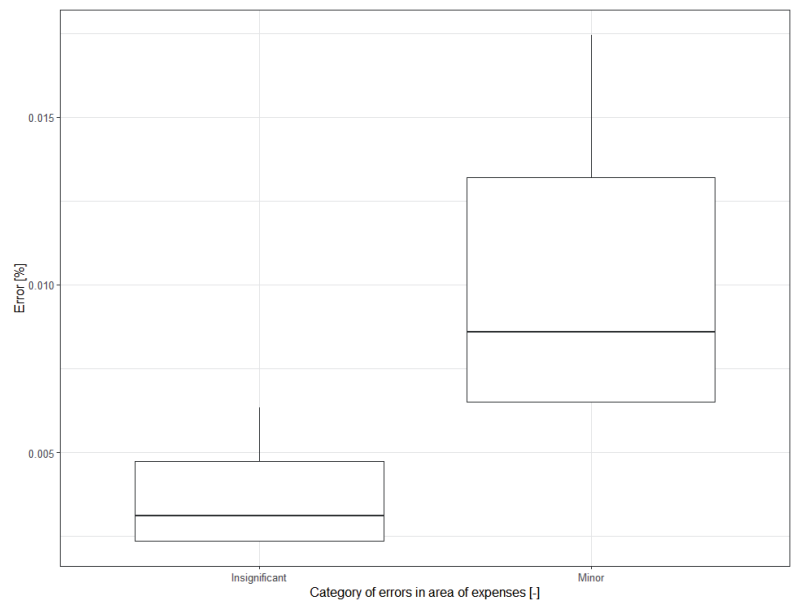

Fig. 4 - Impacts of errors in the area of expenses

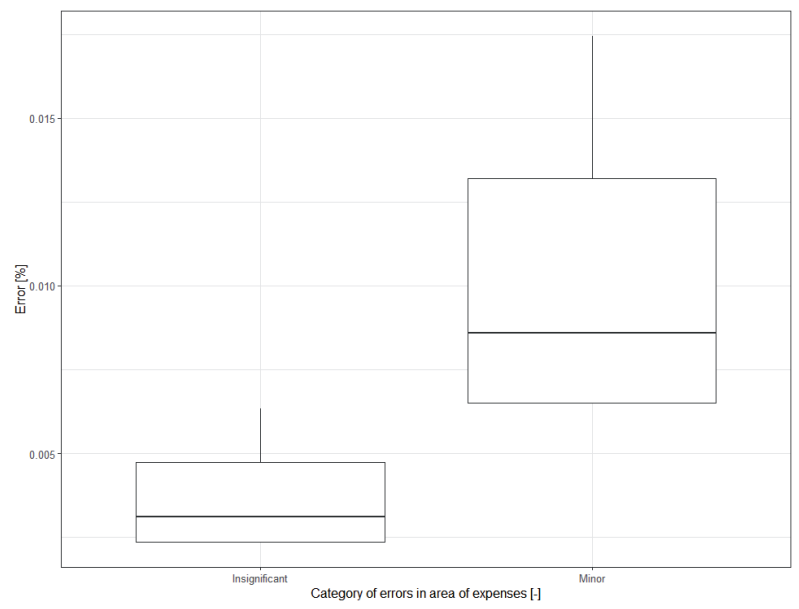

Fig. 5 - Impacts of errors in the area of revenues

Although the percentage error rate for minor errors is only $21.6 \%$, compared with $78.4 \%$ for insignificant errors, the average for minor errors in expenses is $36.3 \%$ higher than for insignificant errors. 
In comparison, a two-population t-test of independency was used to compare the two sets of data for expenses. On the basis of this comparison, a judgment was made regarding the two basic sample sets. Based on this test, we sought to verify one of these hypotheses:

$\mathrm{H}_{0}$ - Insignificant errors in the expenses area influence economic indicators in the same way as do minor errors.

Alternative hypothesis

$\mathrm{H}_{1}$ - Insignificant errors in the expenses area do not influence economic indicators in the same way as do minor errors.

We performed the test at a $5 \%$ level of significance. Results of the test were as that $t(4)=-2.9385$ with $\mathrm{p}$-value $=0.03204$. As $\mathrm{p}$-value is below value of 0.05 we have sufficient evidence to decline zero hypothesis in favour of alternative hypothesis. From this we can assume that impacts of errors on expenses are different between minor and insignificant errors.

The results for minor errors are listed in Table 6.

Tab. 6 - The impact of minor errors on economic indicators. Source: authors' own

\begin{tabular}{|l|l|l|}
\hline $\begin{array}{l}\text { Impact of errors on eco- } \\
\text { nomic indicators }\end{array}$ & $\begin{array}{l}\text { Minor errors in the area of } \\
\text { expenses } \\
0.1 \%-0.9 \% \text { of error rate }\end{array}$ & $\begin{array}{l}\text { Minor errors in the area of } \\
\text { revenues } \\
0.1 \%-0.9 \% \text { of error rate }\end{array}$ \\
\hline EVA & $0.00814 \%$ & $0.00651 \%$ \\
\hline EBITDA & $0.01627 \%$ & $0.01319 \%$ \\
\hline Z-score & $0.00814 \%$ & $0.00651 \%$ \\
\hline ROS & $0.01074 \%$ & $0.01745 \%$ \\
\hline ROC & $0.02181 \%$ & $0.00859 \%$ \\
\hline & \multicolumn{2}{|l}{$\%$} \\
\hline Arithmetic mean & $0.01302 \%$ & $0.01045 \%$ \\
\hline Spread & $0.0000281 \%$ & $0.0000182 \%$ \\
\hline Standard deviation & $0.00530 \%$ & $0.00427 \%$ \\
\hline
\end{tabular}

In comparison, a two-population t-test of independency was used to compare the two sets of data for expenses. On the basis of this comparison, a judgment was made regarding the two basic sample sets. Based on this test, we sought to verify one of these hypotheses:

$\mathrm{H}_{0}$ - Insignificant errors in the revenue area influence economic indicators in the same way as do minor errors.

Alternative hypothesis

$\mathrm{H}_{1}$ - Insignificant errors in the revenue area do not influence economic indicators in the same way as do minor errors.

We performed the test at a $5 \%$ level of significance. Results of the test were as that $\mathrm{t}(4)=-2.9408$ with $\mathrm{p}$-value $=0.03203$. As $\mathrm{p}$-value is below value of 0.05 we have sufficient evidence to decline 
zero hypothesis in favour of alternative hypothesis. From this we can assume that impacts of errors on expenses are different between minor and insignificant errors.

\section{CONCLUSION}

The aim of this article was to present the results of research in the field of accounting errors affecting selected economic indicators. The effects of expense and revenue errors on economic indicators were subjected to statistical evaluation. Our hypotheses were subjected to hypothesis testing of the difference between two population means for the testing of revenue, with expenses errors impacts defined. The economic indicators were based on formulas according to which the economic indicators were calculated. The test has shown that a large percentage of insignificant errors will not affect economic indicators as much as a small percentage of minor errors in both the expenses and revenues areas. This research shows that accounting errors can influence the EVA indicator, and thus value for shareholders nor for owners may not be created. EBITDA and profitability indicators are also heavily impacted.

Therefore, in order for errors not to occur and not to affect the reporting ability of financial statements, there is an obligation to have the financial statements audited by an auditor, which is an obligation is based in Czech law on Section 20 of Act No. 563/1991 Coll. However, not all entities are required to be audited, as they do not meet the minimum value of assets, turnover and / or number of employees to be the subject of the statutory audit. It is likely that large accounting entities that meet the audit obligations will make less mistakes, and in micro and small entities the mistakes may be overlooked.

\section{Acknowledgements}

This paper was supported by Project IGA/FaME/2018/014: the influence of specific risk factors of financial statements on a company's competitiveness with an impact on the tax area.

\section{References}

1. Bai, X., Nunez, M., \& Kalagnanam, J. R. (2012). Managing Data Quality Risk in Accounting Information Systems. Information Systems Research, 23 (2), 453-473. http://doi. org/10.1287/isre.1110.0371

2. Bašta, T. (2006). Pricewaterbouse Coopers - Účetní podvody se nedají vyloučit. Retrieved August 24, from http://www.pwc.com/cz/cze/inssol/issues/2006/UcetniPodvody_TB.html

3. Cernusca, L., David, D., Nicolaescu, C., \& Gomol, B. C. (2016). Empirical Study on the Creative Accounting Phenomenon. Studia Universitatis , Vasile Goldis” Arad - Economics Series, 26 (2), 63-87. http://doi.org/10.1515/sues-2016-0010

4. Deaconu, A., Crisan, S., \& Buiga, A. (2016). Value allocation - Contribution and Risk to the Reliability of Financial reporting. Economics and management, 19 (2), https://doi.org/10.15240/ $\mathrm{tul} / 001 / 2016-2-007$

5. Dušek, J. (2011). Jak se vyhnout chybám v úcetnictví (1st ed.). Praha: Grada Publishing.

6. Fridson, Martin S., \& Alvarez, F.. (2011) Financial statement analysis: a practitioner's guide. 4th ed. Hoboken, N.J.: Wiley. 
7. Chaney, P. K., Faccio, M., \& Parley, D. (2011). The quality of accounting information. Journal of Accounting and Economics. 51 (1), 1-45. Retrieved from http://mpra.ub.unimuenchen.de/21116/1/Accrual_quality_12-18-09.pdf

8. Jones, M. J. (2011). Creative Accounting, Fraud and International Accounting Scandals. US: John Wiley \& Sons Inc. http:// doi.org/10.1002/9781119208907

9. Knápková, A., Pavelková, D., \& Šteker, K. (2013). Finanční analýa: komplexní priovodce s príklady (2nd ed.). Praha: Grada Publishing.

10. Kubickova, D., \& Soucek, J. (2013). Management of Receivables in SMEs in the Czech Republic. European Research Studies Journal, 16 (4), 97-112.

11. Krištofik, P., Lament, M., \& Musa, H. (2016). The reporting of non-financial information and the rationale for its standardisation. E+M Ekonomie a Management, 19 (2), 157-175. https://doi.org/10.15240/tul/001/2016-2-011

12. Nusa, I. B. S. (2015) The Influence of Organizational Culture and Structure on Quality of Accounting Information System. International Journal of Scientific \& Technology Research, 4 (5), $257-267$.

13. Otrusinová, M., \& Šteker, K. (2013) An Analysis of Using Accounting Information for Financial Management in Czech Companies. International Journal of Mathematical Models and Methods in Applied Sciences, 7 (4), 436-443.

14. Porter, G. A., \& Norton, C. L. (2015). Using Financial Accounting Information: The Alternative to Debits and Credits. Mason: South-Western Cengage Learning.

15. Puican, L., Avram, M., \& Dutescu, M. (2011). The Importance of Accounting Information Quality in the Performance of Statutory Audit. Annals of University of Craiova - Economic Sciences, 3 (39), 50-55.

16. Turkmen, B. (2016). Errors and Abuses in Financial Accounting and Results. Procedia Economics and Finance, 38 (1), 77-83. http://dx.doi.org/10.1016/S2212-5671 (16)30179-4

17. Zoto, E. (2014). Data quality and accounting information systems. Perspectives of Innovations. Economics and Business, 14 (1), 34-41. http://doi.org/10.15208/pieb.2014.04

\section{Contact information}

Mgr. Eva Kolarova, Ph.D.

Tomas Bata University in Zlin

Faculty of Management and Economics

E-mail:ekolarova@utb.cr.

ORCID: 0000-0002-2067-5262

Ing. Vendula Kolarova

Tomas Bata University in Zlín

Faculty of Management and Economics

E-mail:vkolarova@utb.cz.

ORCID: 0000-0003-4700-4773
Ing. David Homola

Tomas Bata University in Zlin

Faculty of Management and Economics

E-mail:homola@utb.cz. 